\title{
Article \\ Organic and Elemental Carbon in the Urban Background in an Eastern Mediterranean City
}

\author{
Tareq Hussein ${ }^{1,2, *(\mathbb{D})}$, Xinyang Li ${ }^{2}\left(\mathbb{D}\right.$, Zaid Bakri ${ }^{1,3}$, Andres Alastuey ${ }^{4} \mathbb{D}$, Sharif Arar ${ }^{5}$, Afnan Al-Hunaiti ${ }^{5}$, \\ Mar Viana ${ }^{4} \mathbb{D}$ and Tuukka Petäjä ${ }^{2}$
}

1 Department of Physics, School of Science, The University of Jordan, Amman 11942, Jordan; zbakri@mtu.edu or zyd8190198@ju.edu.jo

2 Institute for Atmospheric and Earth System Research (INAR/Physics), University of Helsinki, FI-00014 Helsinki, Finland; xinyang.li@helsinki.fi (X.L.); tuukka.petaja@helsinki.fi (T.P.)

3 Physics Department and Atmospheric Sciences Program, Michigan Technological University, Houghton, MI 49931, USA

4 Institute of Environmental Assessment and Water Research (IDAEA-CSIC), 08034 Barcelona, Spain; andres.alastuey@idaea.csic.es (A.A.); mar.viana@idaea.csic.es (M.V.)

5 Department of Chemistry, School of Science, The University of Jordan, Amman 11942, Jordan; s.arar@ju.edu.jo (S.A.); a.alhunaiti@ju.edu.jo (A.A.-H.)

* Correspondence: tareq.hussein@helsinki.fi or t.hussein@ju.edu.jo

\section{check for}

updates

Citation: Hussein, T.; Li, X.; Bakri, Z.; Alastuey, A.; Arar, S.; Al-Hunaiti, A.; Viana, M.; Petäjä, T. Organic and Elemental Carbon in the Urban Background in an Eastern Mediterranean City. Atmosphere 2022, 13, 197. https://doi.org/10.3390/ atmos13020197

Academic Editors: Elena Hristova, Manousos Ioannis Manousakas, Anikó Angyal and Maria Gini

Received: 2 December 2021

Accepted: 24 January 2022

Published: 26 January 2022

Publisher's Note: MDPI stays neutral with regard to jurisdictional claims in published maps and institutional affiliations.

Copyright: (c) 2022 by the authors. Licensee MDPI, Basel, Switzerland. This article is an open access article distributed under the terms and conditions of the Creative Commons Attribution (CC BY) license (https:/ / creativecommons.org/licenses/by/ $4.0 /)$.

\begin{abstract}
The Mediterranean region is an important area for air pollution as it is the crossroads between three continents; therefore, the concentrations of atmospheric aerosol particles are influenced by emissions from Africa, Asia, and Europe. Here we concentrate on an eleven-month time series of the ambient concentration of organic carbon (OC) and elemental carbon (EC) between May 2018March 2019 in Amman, Jordan. Such a dataset is unique in Jordan. The results show that the OC and EC annual mean concentrations in $\mathrm{PM}_{2.5}$ samples were $5.9 \pm 2.8 \mu \mathrm{g} \mathrm{m}^{-3}$ and $1.7 \pm 1.1 \mu \mathrm{g} \mathrm{m}^{-3}$, respectively. It was found that the majority of OC and EC concentrations were within the fine particle fraction $\left(\mathrm{PM}_{2.5}\right)$. During sand and dust storm (SDS) episodes OC and EC concentrations were higher than the annual means; the mean values during these periods were about $9.6 \pm 3.5 \mu \mathrm{g} \mathrm{m}^{-3}$ and $2.5 \pm 1.2 \mu \mathrm{g} \mathrm{m}^{-3}$ in the $\mathrm{PM}_{2.5}$ samples. Based on this, the SDS episodes were identified to be responsible for an increased carbonaceous aerosol content as well as $\mathrm{PM}_{2.5}$ and $\mathrm{PM}_{10}$ content, which may have direct implications on human health. This study encourages us to perform more extensive measurements during a longer time period and to include an advanced chemical and physical characterization for urban aerosols in the urban atmosphere of Amman, which can be representative of other urban areas in the region.
\end{abstract}

Keywords: urban air quality; $\mathrm{PM}_{10} ; \mathrm{PM}_{2.5} ; \mathrm{OC}$; EC

\section{Introduction}

Carbonaceous aerosols found in particulate matter (PM) are mainly in the form of elemental carbon (EC) and organic carbon (OC) [1-8]. These species of aerosols are of worldwide interest due to their vague origins and complicated source apportionment process [9-11]. On the one hand, incomplete combustion processes and wildfires are the major sources of EC [12,13]. On the other hand, OC sources potentially originate from processes that involve chemical reactions of hydrocarbons [14]. There is a contrast between the effects of OC and EC on the climate; EC is involved in the global warming effect due to its strong light-absorption property $[15,16]$, whereas OC is responsible for cooling the atmosphere mainly because it reflects solar radiation [17]; however, some recent publications have reported that some OC (a newly emerged phrase: brown carbon) can significantly absorb light in the region of 300-400 $\mathrm{nm}$ and could hinder and oppose the general cooling action [18-21]. In terms of health effects, it has been suggested that increased mortality rates and respiratory diseases are related to OC and EC content exposure [22-32]. 
In urban areas, OC and EC originate from many sources, both local and regional. They can be transported over long distances, reaching thousands of kilometers away from their source [33-42]. For instance, OC comprises thousands of individual molecules that can be directly emitted as primary emissions or can be formed in the atmosphere from semi-volatile and gaseous precursors over the course of minutes to days. EC is directly emitted from combustion processes, such as mobile sources or biomass burning.

The Mediterranean basin, including the Eastern Mediterranean region, is considered a climate change hotspot due to warming tendencies and decreased precipitation processes [43]. The Eastern Mediterranean region, especially Jordan, is impacted by anthropogenic emissions as well as natural sources (e.g., sand and dust storm episodes (SDS)), which are found to affect PM concentrations in the region [44]. Since there is a lack of information on $\mathrm{OC}$ and $\mathrm{EC}$ concentrations and ratios in the region, there is a need to monitor and explore their aerosol concentrations, sources, and compositions in this region. Chemical analysis of ambient PM enables the identification of aerosol sources and addressing the relative contributions of different processes. In this study, we aim at characterizing $\mathrm{PM}_{10}$ and $\mathrm{PM}_{2.5}$ with respect to OC and EC during May 2018-March 2019 in Amman, which is a typical city in the region. This study is important to the Middle East and North Africa region (MENA), especially Jordan, where the measurements took place, as it provides background information for urban aerosol chemical composition. This can be utilized to explore aerosol impacts on climate and health in follow-up analyses.

\section{Materials and Methods}

\subsection{Aerosol Measurement}

The measurement campaign took place during May 2018-March 2019 on the rooftop (about $20 \mathrm{~m}$ above the ground) of the Department of Physics at the campus of the University of Jordan ( $32^{\circ} 0129^{\prime} \mathrm{N}, 35^{\circ} 8738^{\prime} \mathrm{E}$ ) (Figure S1). This was classified as an urban background in the northern part of Amman, Jordan. The surroundings are a mixture of residential areas and road networks [44].

The aerosol measurement instrumentation included two high-volume samplers (model CAV-A/mb, MCV, S.A., Barcelona, Spain) for $\mathrm{PM}_{10}$ and $\mathrm{PM}_{2.5}$. The cascade head (model PM1025-CAV, MCV, S.A., Barcelona, Spain) was equipped with a filter (Pallflex, PALLXQ250ETDS0150, TISSUQUARTZ 2500 QAT-UP, Merek, New Jersy, USA), which has a diameter of $15 \mathrm{~cm}$. The flow rate was $30 \mathrm{~m}^{3} \mathrm{~h}^{-1}$ and the sampler automatically recorded the overall mean temperature and pressure during the sampling session.

The $\mathrm{PM}_{10}$ and $\mathrm{PM}_{2.5}$ sampling was performed for 24 h every 6 days. We obtained 51 and 48 valid samples for $\mathrm{PM}_{10}$ and $\mathrm{PM}_{2.5}$, respectively. We also collected several blank samples, which were needed as an accuracy control of the sampling [45].

\subsection{Gravimetric and OC/EC Chemical Analysis}

Before performing the chemical analyses (including organic carbon (OC) and elemental carbon (EC)), the $\mathrm{PM}_{10}$ and $\mathrm{PM}_{2.5}$ mass concentrations were determined by gravimetric analysis, which was performed according to the EN1234-1. Accordingly, the particulate matter concentration can be calculated from the filter's weights (difference between postweight $\left(m_{\text {post }}\right)$ and pre-weight $\left.\left(m_{\text {pre }}\right)\right)$ divided by the sampling flow rate $\left(Q\left(30 \mathrm{~m}^{3} \mathrm{~h}^{-1}\right)\right)$ and sampling period $(\Delta t=24 \mathrm{~h})$.

A quarter of each sampled filter was taken to the OC and EC analysis according to the EUSAAR2 protocol employing a Sunset Laboratory Dual-Optical Carbonaceous Analyzer [46-48]. The uncertainty in our analysis was approximately $0.2,0.1,0.3 \mu \mathrm{g} \mathrm{m}^{-3}$, respectively, for $\mathrm{OC}, \mathrm{EC}$, and $\mathrm{TC}$.

\subsection{Ambient Conditions and Air Mass Trajectories Measurement}

In addition to the aerosol measurement, the ambient conditions (T, P, RH, wind speed, and direction) were monitored with 5 min resolution (Table S1, Figures S2, S3, and S5-S8) by using a weather station (WH-1080, Clas Ohlson: Art. no. 36-3242). We also calculated 
the air mass back-trajectories (Hybrid Single-Particle Lagrangian Integrated Trajectory (HYSPLIT) [49,50]. The trajectories were calculated for the previous four days on an hourly basis at arrival heights 100, 500, and $1500 \mathrm{~m}$ above ground level.

\section{Results and Discussion}

\subsection{An Overview of PM Concentrations}

Throughout the measurement period, the $24 \mathrm{~h} \mathrm{PM}_{10}$ was within the range 20-190 $\mu \mathrm{g} \mathrm{m}^{-3}$ (average $64 \pm 39 \mu \mathrm{g} \mathrm{m}^{-3}$ ) and the $\mathrm{PM}_{2.5}$ was $15-190 \mu \mathrm{g} \mathrm{m}^{-3}$ (average $47 \pm 32 \mu \mathrm{g} \mathrm{m}^{-3}$ ) - see Table S2 in the Supplementary Material. On average, approximately $80 \%$ of the $\mathrm{PM}_{10}$ was within the $\mathrm{PM}_{2.5}$ fraction. According to the Jordanian standards of ambient air quality (JS-1140/2006: annual mean $\mathrm{PM}_{10}$ and $\mathrm{PM}_{2.5}$ must not exceed $70 \mu \mathrm{g} \mathrm{m}^{-3}$ and $15 \mu \mathrm{g} \mathrm{m}^{-3}$ and $24 \mathrm{~h}$ mean must not exceed $120 \mathrm{\mu g} \mathrm{m}^{-3}$ and $65 \mathrm{\mu g} \mathrm{m}^{-3}$, respectively), the observed overall mean $\mathrm{PM}_{10}$ was below its annual limit value but the $\mathrm{PM}_{2.5}$ was three times higher than its limit value. Compared to the World Health Organization (WHO) old air quality guidelines [51] (i.e., before 2021) for $\mathrm{PM}_{10}$ (annual and $24 \mathrm{~h}$ must not exceed $20 \mathrm{\mu g} \mathrm{m}^{-3}$ and $50 \mu \mathrm{g} \mathrm{m}^{-3}$, respectively) and $\mathrm{PM}_{2.5}$ (annual and $24 \mathrm{~h}$ must not exceed $10 \mu \mathrm{g} \mathrm{m}^{-3}$ and $25 \mathrm{gg} \mathrm{m}^{-3}$, respectively), the observed annual concentrations here exceeded the annual guideline. By all means, the reported values here exceeded the new WHO air quality guidelines [52] (i.e., after 2021), which was updated to be tighter than the old guidelines for $\mathrm{PM}_{10}$ (annual and $24 \mathrm{~h}$ must not exceed $15 \mu \mathrm{g} \mathrm{m}^{-3}$ and $45 \mu \mathrm{g} \mathrm{m}^{-3}$, respectively) and $\mathrm{PM}_{2.5}$ (annual and $24 \mathrm{~h}$ must not exceed $5 \mu \mathrm{g} \mathrm{m}^{-3}$ and $15 \mu \mathrm{g} \mathrm{m}^{-3}$, respectively). In general, the reported $\mathrm{PM}_{10}$ concentrations in Jordan were higher than the concentrations reported by the WHO (2018) in urban, suburban, and residential sites in countries around the Mediterranean Sea in 2016, especially Turkey $\left(52 \pm 18 \mu \mathrm{g} \mathrm{m}^{-3}\right)$, Italy $\left(25 \pm 6 \mu \mathrm{g} \mathrm{m}^{-3}\right)$, Greece $\left(52 \pm 18 \mu \mathrm{g} \mathrm{m}^{-3}\right)$, Cyprus $\left(37 \pm 6 \mu \mathrm{g} \mathrm{m}^{-3}\right)$, and Malta $\left(38 \pm 8 \mu \mathrm{g} \mathrm{m}^{-3}\right)$. These concentrations were lower than concentrations observed in the following regions: Kuwait $\left(130 \pm 35 \mathrm{\mu g} \mathrm{m}^{-3}\right)$, Palestine $\left(90 \mu \mathrm{g} \mathrm{m}^{-3}\right)$, Egypt $\left(249-284 \mu_{\mathrm{g} \mathrm{m}}^{-3}\right)$, and the United Arab Emirates $\left(122-153 \mu \mathrm{g} \mathrm{m}^{-3}\right)$.

\subsection{Organic and Elemental Carbon Concentrations}

The TC and OC concentrations followed a rather similar temporal variation as that for the PM concentrations (Figures 1 and 2). The OC concentrations observed in the $\mathrm{PM}_{2.5}$ samples were in the range 1.2-17.1 $\mu \mathrm{g} \mathrm{m}^{-3}$ (annual mean $5.9 \pm 2.8 \mu \mathrm{g} \mathrm{m}^{-3}$ ), the EC concentrations were $0.45-6.1 \mathrm{\mu g} \mathrm{m}^{-3}$ (annual mean of $1.7 \pm 1.1 \mathrm{\mu g} \mathrm{m}^{-3}$ ), and the TC concentrations were $1.7-23.2 \mu \mathrm{g} \mathrm{m}^{-3}$ (annual mean $7.6 \pm 3.5 \mu \mathrm{g} \mathrm{m}^{-3}$ ). As for the $\mathrm{PM}_{10}$, they were 2.2-17.5 $\mu \mathrm{g} \mathrm{m}^{-3}$ (annual mean of $6.5 \pm 3.0 \mu \mathrm{g} \mathrm{m}^{-3}$ ), $0.5-5.5 \mu \mathrm{g} \mathrm{m}^{-3}$ (annual mean of $1.9 \pm 1.1 \mathrm{\mu g} \mathrm{m}^{-3}$ ), and 2.7-22.4 $\mu \mathrm{g} \mathrm{m}^{-3}$ (annual mean $8.4 \pm 3.8 \mu \mathrm{g} \mathrm{m}^{-3}$ ), respectively, for the OC, EC, and TC concentrations. On average, the $\mathrm{PM}_{2.5}$ contained about $14 \%, 4 \%$, and $18 \%$ OC, EC, and TC (Figure 3). As for the $\mathrm{PM}_{10}$, it was about $12 \%, 4 \%, 15 \%$, respectively. As expected for an urban background, the TC was dominated by OC for both the $\mathrm{PM}_{2.5}$ and $\mathrm{PM}_{10}$ (Figure 4); this indicates a dominating fraction of organic emissions from anthropogenic activities rather than natural emissions, as also reported elsewhere [53-60].

According to $\mathrm{PM}_{2.5}$ observations elsewhere in the region (mostly outside of Jordan; see Table 1), the OC and EC concentrations reported herein are comparable. A greater interest might be the extremely high OC concentrations in Beijing $\left(29.1 \mathrm{\mu g} \mathrm{m}^{-3}\right)$ and Tehran $\left(15.35 \pm 6.05 \mu \mathrm{g} \mathrm{m}^{-3}\right)$ with corresponding $\mathrm{PM}_{2.5}$ concentrations of $115 \mu \mathrm{g} \mathrm{m}^{-3}$ and $41.2 \mu \mathrm{g} \mathrm{m}^{-3}$, respectively [61,62]. As for $\mathrm{PM}_{10}$ observations elsewhere (Table 2), the OC concentrations reported here are generally lower than those reported in other regions in the world.

The $\mathrm{PM}_{10}$ records in Table 2 show a clear contrast with the OC concentrations. A relatively high $\mathrm{OC}_{10}$ concentration record was observed in Lahore, with a value of $63 \mu \mathrm{g} \mathrm{m}^{-3}$, while a very low concentration was observed in Spain, with a value of $4 \mu \mathrm{g} \mathrm{m}^{-3}$. For both $\mathrm{PM}_{2.5}$ and $\mathrm{PM}_{10}$ the $\mathrm{OC}$ to $\mathrm{EC}$ ratio was generally higher in the summertime than that in the wintertime (Figure 5). The OC/EC ratio in the $\mathrm{PM}_{2.5}$ was approximately $5.6 \pm 1.5$ 
during May-August and was approximately $2.8 \pm 0.9$ during November-March. As for the $\mathrm{PM}_{10}$, the ratio was approximately $4.9 \pm 1.2$ and $3.1 \pm 1.4$, respectively.

During the measurement period, the ratio $\mathrm{PM}_{2.5} / \mathrm{PM}_{10}$ was close to one on some days. This was basically due to the domination of fine aerosols, i.e., the absence of sand and dust storm (SDS) episodes. On these occasions, the $\mathrm{OC}_{2.5}$ was $4.0-17.1 \mu \mathrm{g} \mathrm{m}^{-3}$ and the $\mathrm{OC}_{10}$ was 2.4-15.9 $\mu \mathrm{g} \mathrm{m}^{-3}$. The corresponding $\mathrm{EC}_{2.5}$ was $0.7-6.1 \mu \mathrm{g} \mathrm{m}^{-3}$ and $\mathrm{EC}_{10}$ was $0.9-5.5 \mu \mathrm{g} \mathrm{m}^{-3}$.

(a)

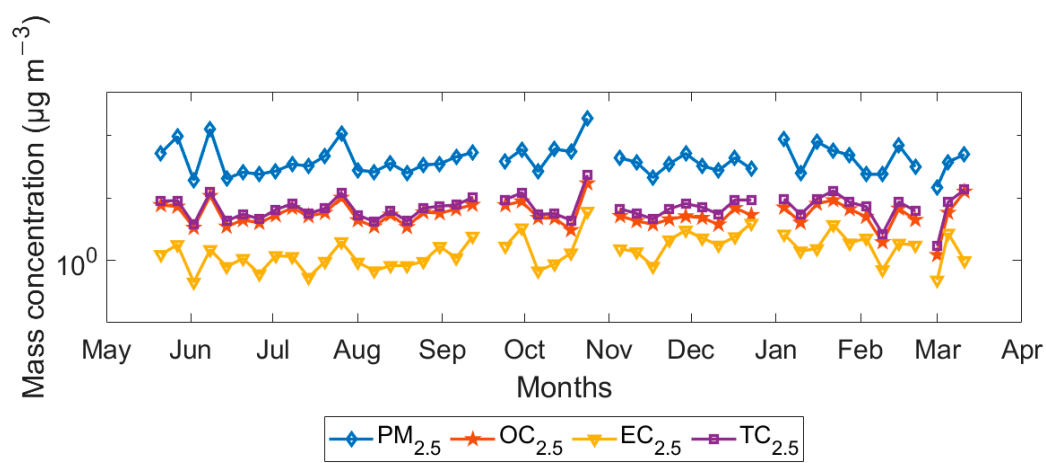

(b)

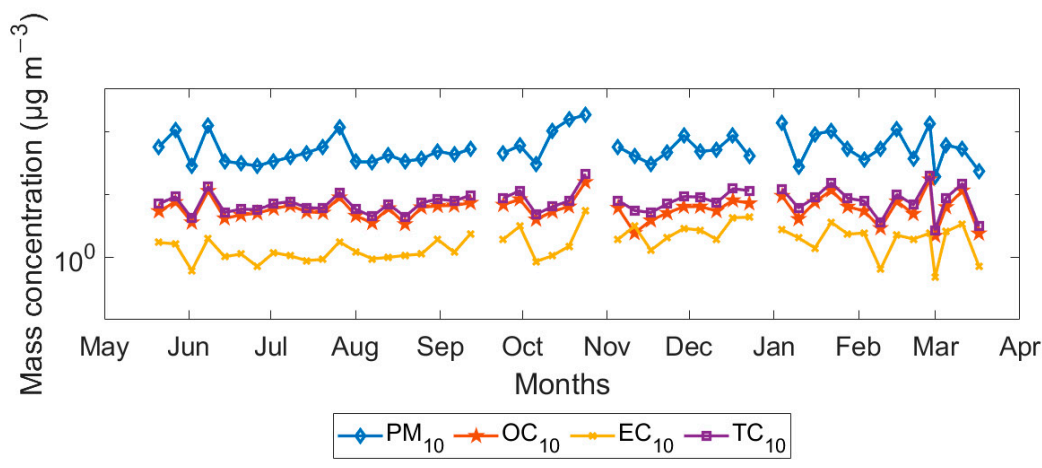

Figure 1. PM and corresponding OC, EC, and TC concentrations: (a) fine fraction; (b) coarse fraction.

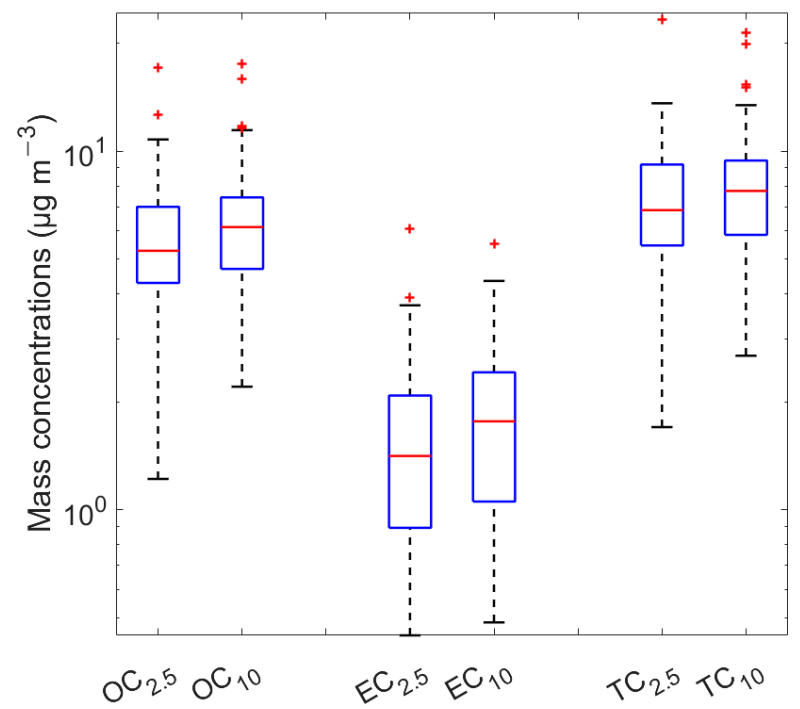

Figure 2. Boxplot of OC, EC, and TC within the $\mathrm{PM}_{2.5}$ and $\mathrm{PM}_{10}$. The box plot represents 25 th and 75th percentiles and median (red line), the bars represent the 5th and 95th percentiles, and the plus symbols indicate outlayers. 
(a)

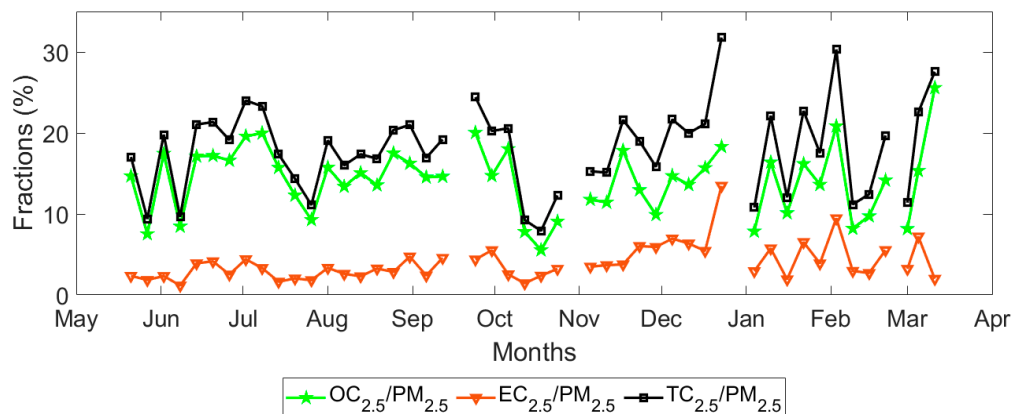

(b)

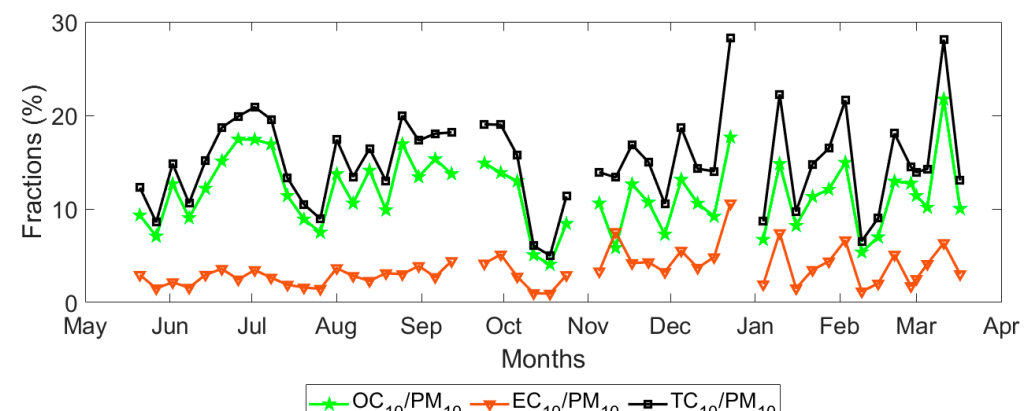

Figure 3. OC, EC, and TC contents (mass concentrations, \%) in the corresponding PM concentrations: (a) fine fraction; (b) coarse fraction.

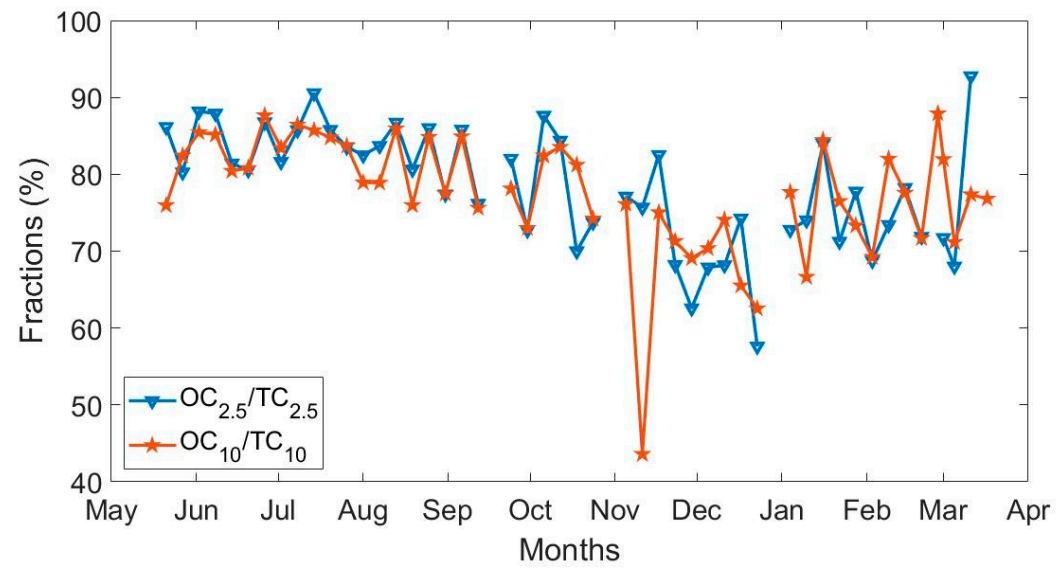

Figure 4. The ratio $\mathrm{OC} / \mathrm{TC}$ in the $\mathrm{PM}_{2.5}$ and $\mathrm{PM}_{10}$ concentrations.

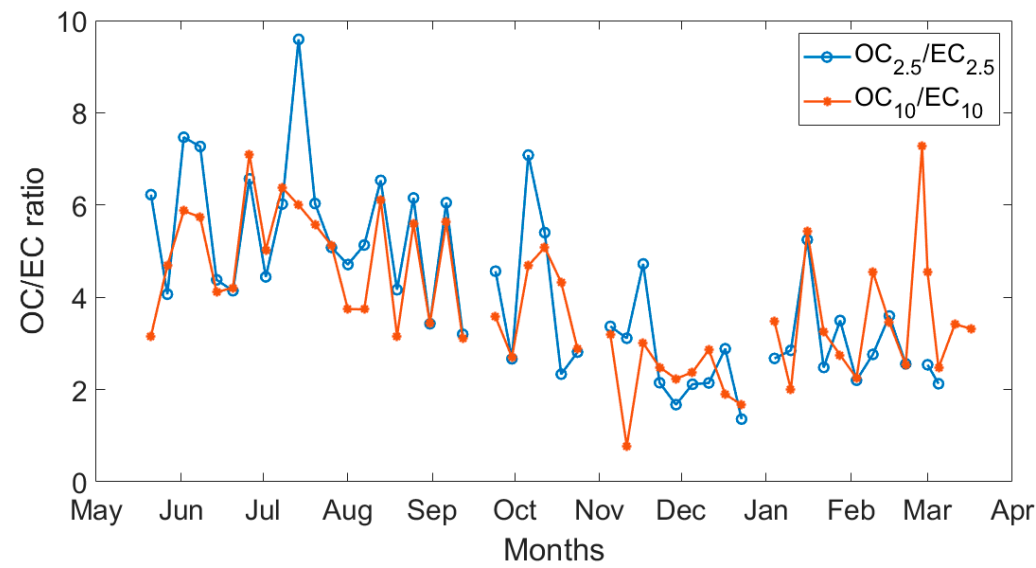

Figure 5. Variation of $\mathrm{OC}$ and $\mathrm{EC}$ ratio in $\mathrm{PM}_{2.5}$ and $\mathrm{PM}_{10}$ during the measurement period. 
Table 1. OC and EC concentrations in $\mathrm{PM}_{2.5}$ reported in Asia, North America, Middle East, and Europe.

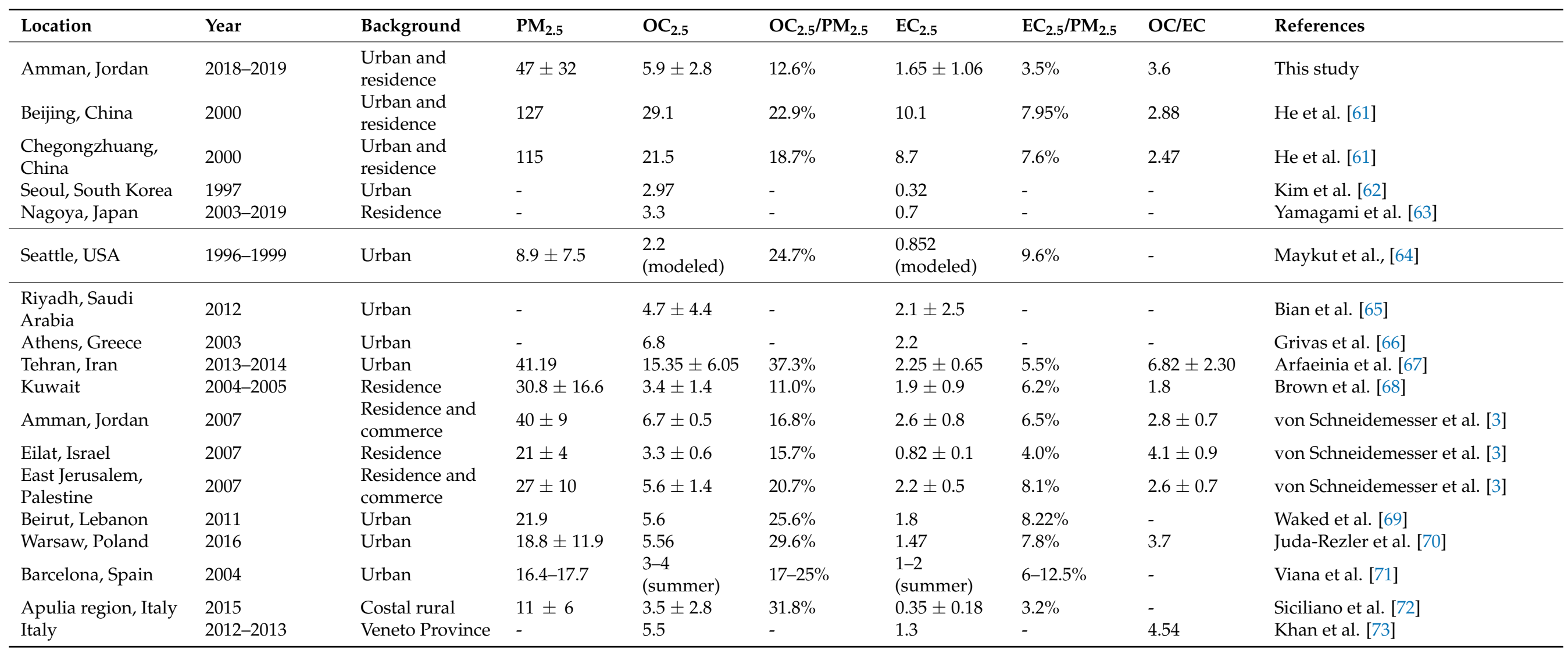


Table 2. OC and EC concentrations in PM10 reported in Asia, North America, Middle East, and Europe.

\begin{tabular}{|c|c|c|c|c|c|c|c|c|c|}
\hline Location & Year & Background & $\mathbf{P M}_{10}$ & $\mathrm{OC}_{10}$ & $\mathrm{OC}_{10} / \mathrm{PM}_{10}$ & $\mathrm{EC}_{10}$ & $\mathrm{EC}_{10} / \mathrm{PM}_{10}$ & OC/EC & References \\
\hline Amman, Jordan & 2018-2019 & $\begin{array}{l}\text { Urban and } \\
\text { residence }\end{array}$ & $64 \pm 39$ & $6.5 \pm 3.04$ & $10.2 \%$ & $1.9 \pm 1.07$ & $3.0 \%$ & 3.4 & This study \\
\hline Taiyuan, China & 2001-2002 & Urban & 146.36 & $\begin{array}{c}25.89 \\
\text { (summer) }\end{array}$ & $17.7 \%$ & $\begin{array}{c}6.82 \\
\text { (summer) }\end{array}$ & $4.7 \%$ & - & Tian et al. [74] \\
\hline Seoul, South Korea & 1994 & Urban & - & 11.1 & - & 8.39 & - & - & Kim et al. [66] \\
\hline $\begin{array}{l}\text { Indo-Gangetic Plain, } \\
\text { India }\end{array}$ & 2015-2016 & Residence & $283 \pm 61$ & $\begin{array}{l}74.2 \pm 14 \\
\text { (Night) }\end{array}$ & $26.2 \%$ & - & - & - & Arif et al. [75] \\
\hline $\begin{array}{l}\text { Indo-Gangetic Plain, } \\
\text { India }\end{array}$ & 2015-2016 & Residence & $167 \pm 45$ & $\begin{array}{l}44.3 \pm 8.9 \\
\quad \text { (Day) }\end{array}$ & $26.5 \%$ & - & - & - & Arif et al. [75] \\
\hline Mira Loma, USA & 2001 & Urban plume & - & $15.91 \pm 6.81$ & - & $1.56 \pm 0.56$ & - & - & Salmon et al. [76] \\
\hline Lahore, Pakistan & 2010 & Urban & 406.2 & 63 & $15.5 \%$ & 21 & $5.2 \%$ & $3.9 \pm 1.6$ & Alam et al. [77] \\
\hline Thessaloniki, Greece & 2012 & Urban & $51.1 \pm 14$ & $11.3 \pm 5.0$ & $22.1 \%$ & $6.56 \pm 2.14$ & $12.8 \%$ & $1.96 \pm 1.16$ & Samara et al. [78] \\
\hline Barcelona, Spain & 2004 & Urban & $29.5 \pm 8.5$ & $\begin{array}{c}4 \\
\text { (summer) }\end{array}$ & $13.6 \%$ & $\begin{array}{c}1 \\
\text { (summer) }\end{array}$ & $3.4 \%$ & - & Viana et al. [71] \\
\hline Budapest, Hungary & 2002 & Near-city & 54 & 11 & $20.4 \%$ & 3.6 & $6.7 \%$ & - & Salma et al. [79] \\
\hline Apulia region, Italy & 2015 & Coastal rural & $23 \pm 14$ & $5 \pm 4$ & $21.7 \%$ & $0.41 \pm 0.19$ & $1.8 \%$ & 11.3 & Siciliano et al. [72] \\
\hline
\end{tabular}




\subsection{Changes during Sand and Dust Storms (SDS)}

As per our previous analysis [44], the SDS episodes were classified into three categories based on their origin: S (Sahara), SL (Saharan and Levant), SA (Sahara and Arabia), and SLA (Sahara, Levant, and Arabia); kindly see more information in the Supplementary Materials. During SDS episodes, the mean $\mathrm{OC}_{2.5}$ and $\mathrm{EC}_{2.5}$ were $9.6 \pm 3.5 \mu \mathrm{g} \mathrm{m}^{-3}$ and $2.5 \pm 1.2 \mu \mathrm{g} \mathrm{m}^{-3}$, respectively (Figure 6). During non-dust episodes, the $\mathrm{OC}_{2.5}$ and $\mathrm{EC}_{2.5}$ were $5.4 \pm 1.8 \mu \mathrm{g} \mathrm{m}^{-3}$ and $1.7 \pm 0.9 \mu \mathrm{g} \mathrm{m}^{-3}$, respectively (Figure 7). As for $\mathrm{PM}_{10}$, the $\mathrm{OC}_{10}$ and $\mathrm{EC}_{10}$ were $8.0 \pm 3.5 \mu \mathrm{g} \mathrm{m}^{-3}$ and $2.4 \pm 1.3 \mu \mathrm{g} \mathrm{m}^{-3}$ during dust episodes and $5.2 \pm 2.0 \mu \mathrm{g} \mathrm{m}^{-3}$ and $2.4 \pm 1.3 \mu \mathrm{g} \mathrm{m}^{-3}$ during non-dust episodes, respectively.
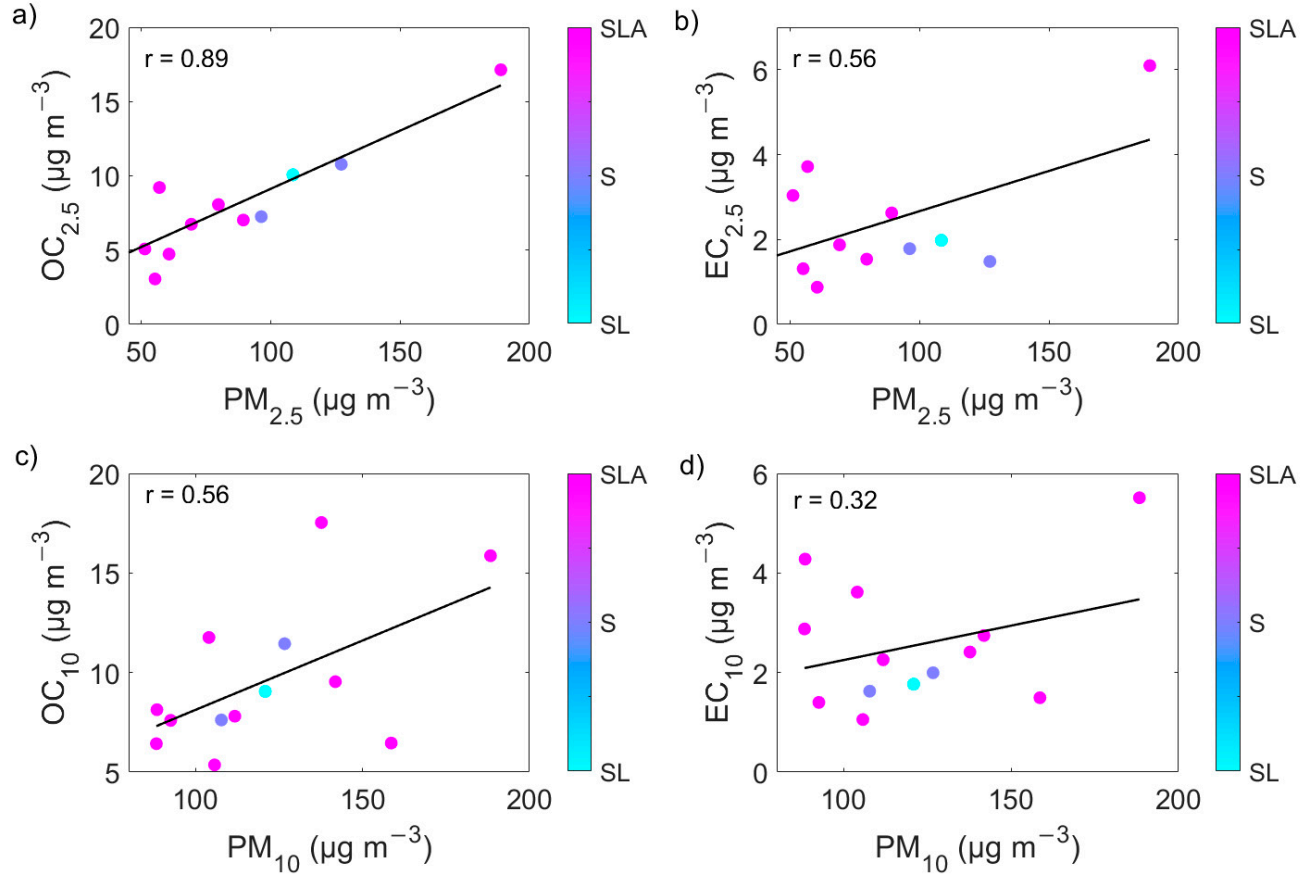

Figure 6. OC and EC versus the corresponding PM concentrations on days (13 in total) with sand and dust storm (SDS) episodes: (a) the OC content (here called $\mathrm{OC}_{2.5}$ ) versus its corresponding $\mathrm{PM}_{2.5}$, (b) the EC versus (here called $\mathrm{EC}_{2.5}$ ) within its corresponding $\mathrm{PM}_{2.5}$, (c) the OC content (here called $\mathrm{OC}_{10}$ ) versus its corresponding $\mathrm{PM}_{10}$, and $(\mathbf{d})$ the $\mathrm{EC}$ versus (here called $\mathrm{EC}_{10}$ ) within its corresponding $\mathrm{PM}_{10}$.

It was apparent that the concentrations of OC were greatly influenced by the type of aerosols (i.e., coarse dust particles) but the $\mathrm{EC}$ was not affected as much. The $\mathrm{OC}_{2.5} / \mathrm{PM}_{2.5}$ during the SDS episodes carried the highest correlation coefficient of 0.89 , which was expected since OC mostly exists in accumulation mode $(0.1-1 \mu \mathrm{m})$ particles in $\mathrm{PM}_{2.5}$ [80]; it also confirmed the dominance of $\mathrm{OC}_{2.5}$ in the total carbon content. By comparing both the $\mathrm{EC}_{\mathrm{x}} / \mathrm{PM}_{\mathrm{x}}$ in the corresponding $\mathrm{PM}_{2.5}$ and $\mathrm{PM}_{10}$, we observed that, during SDS episodes, the EC and PM in the fine particle size range were more correlated $(r=0.556$, Figure $6 \mathrm{~b})$, whereas they were much less correlated $(r=0.32$, Figure $6 \mathrm{~d})$ in the coarse particle size range. On the other hand, the $\mathrm{r}$ values for EC and PM on both particle size ranges were very close on non-SDS days (Figure 7b,d). This result suggests that, during SDS episodes, aerosols have a high potential of transporting OC, which dramatically increased the concentration of OC to the measurement site from other urban centers in the region. As previously mentioned, the regular atmospheric EC concentrations remain at around $2-3 \mu \mathrm{g} \mathrm{m}^{-3}$. 

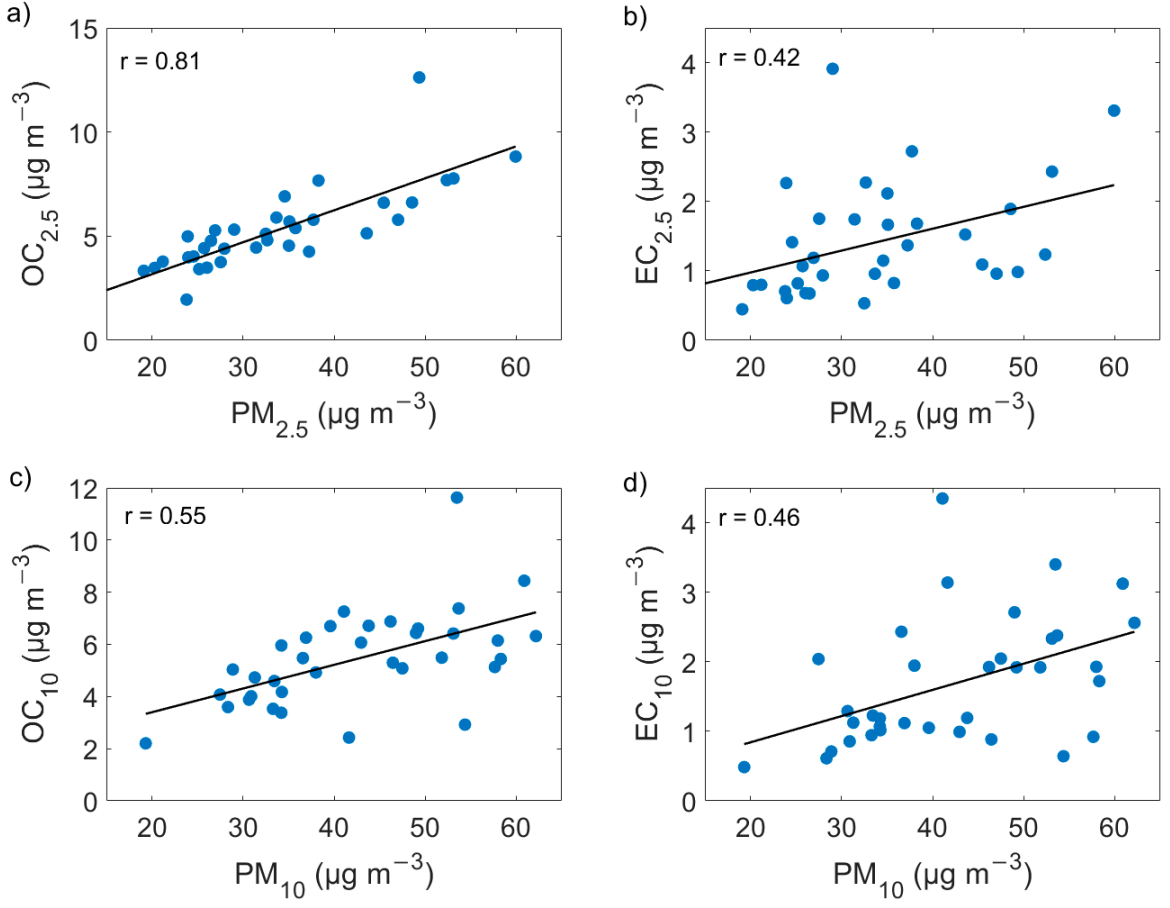

Figure 7. OC and EC versus the corresponding PM concentrations on days (39 in total) without sand and dust storm (SDS) episodes: (a) the $\mathrm{OC}$ content (here called $\mathrm{OC}_{2.5}$ ) versus its corresponding $\mathrm{PM}_{2.5}$, (b) the EC versus (here called $\mathrm{EC}_{2.5}$ ) within its corresponding $\mathrm{PM}_{2.5}$, (c) the OC content (here called $\mathrm{OC}_{10}$ ) versus its corresponding $\mathrm{PM}_{10}$, and (d) the EC versus (here called $\mathrm{EC}_{10}$ ) within its corresponding $\mathrm{PM}_{10}$.

\section{Conclusions}

General monitoring requirements for air quality and assessment include ambient air $\mathrm{PM}_{2.5}$ and $\mathrm{PM}_{10}$, in addition to some gaseous pollutants; however, there is a lack of monitoring of OC and EC concentrations in many parts of the world. Unfortunately, there has been a lack of information regarding OC, EC, and TC in the Eastern Mediterranean region. In this study, we characterized the $\mathrm{PM}_{10}$ and $\mathrm{PM}_{2.5}$ with respect to OC/EC during an eleven-month time series (May 2018-March 2019) in the urban atmosphere of Amman, Jordan, which is a typical Eastern Mediterranean city.

The OC found in the $\mathrm{PM}_{2.5}$ fraction (i.e., $\mathrm{OC}_{2.5}$ ) was within the range of $1.2-17.1 \mu \mathrm{g} \mathrm{m}^{-3}$. The corresponding $\mathrm{EC}_{2.5}$ was within the range of $0.6-6.1 \mu \mathrm{g} \mathrm{m}^{-3}$. As for the $\mathrm{PM}_{10}$ fraction, the $\mathrm{OC}_{10}$ and $\mathrm{EC}_{10}$ were within the range of $2.2-17.5 \mu \mathrm{g} \mathrm{m}^{-3}$ and $0.5-5.5 \mu \mathrm{g} \mathrm{m}^{-3}$, respectively. In percentages, about $14 \%$ and $3.9 \%$ of the $\mathrm{PM}_{2.5}$ were $\mathrm{OC}$ and $\mathrm{EC}$, respectively. In the PM10, 11.6\% and 3.5\% were OC and EC, respectively. These results indicate the domination of anthropogenic activities' emissions over natural sources' emissions.

Sand and dust storm (SDS) episodes were observed during the measurement campaign. During SDS episodes, the mean $\mathrm{OC}_{2.5}$ was approximately $9.6 \pm 3.5 \mu \mathrm{g} \mathrm{m}^{-3}$, which is much higher than the annual mean (i.e., $5.9 \pm 2.8 \mu \mathrm{g} \mathrm{m}^{-3}$ ). Similarly, the $\mathrm{EC}_{2.5}$ approached a mean concentration of $2.5 \pm 1.2 \mu \mathrm{g} \mathrm{m}^{-3}$ during the SDS episodes, while it had an annual mean of $1.7 \pm 1.1 \mu \mathrm{g} \mathrm{m}^{-3}$. This is evidence of the SDS episodes' role in introducing particulate phase pollutants other than the coarse mode dust particles to the measurement site, or more generally, to the whole region.

This study indicated that a large fraction of carbonaceous aerosol mass most likely originates from anthropogenic activities rather than natural sources. Future studies with detailed source apportionment tools [81,82] are needed to verify this result. Accurate classification of the origins of this type of aerosols can be useful in regulating the involved activities. 
Supplementary Materials: The following are available online at https:/ / www.mdpi.com/article/ 10.3390/atmos13020197/s1, Figure S1:Maps showing (a) the Mediterranean Sea region with Jordan highlighted in red, (b) Jordan with highlights on the geographical locations of main cities, (c) road network and the campus of the University of Jordan (red shaded area) inside Amman, and (d) details of the campus of the University of Jordan with the sampling location (red shaded area) at the middle of the campus, Figure S2:Time series of weather conditions during 1 May 2018-19 March 2019 presented as hourly, daily, and monthly means for (a) ambient temperature, (b) relative humidity, (c) absolute pressure, and (d) wind speed. (e) The rainfall was presented as hourly cumulative precipitation, Figure S3: Back trajectories $(96 \mathrm{~h}$ ) crossing maps at arrival heights (a) $100 \mathrm{~m}$ and (b) $1500 \mathrm{~m}$. The arrival location was the campus of the University of Jordan, Amman, Jordan. These maps were generated from the hourly trajectories during 1 May 2018-31 March 2019, Figure S4: Time series of PM10 and PM2.5 concentrations with markups for sand and dust episodes (SDS) and clean air periods (i.e. PM10 concentrations $\left.<70 \mu \mathrm{g} / \mathrm{m}^{3}\right)$, Figure S5: Back trajectories $(96 \mathrm{~h})$ crossing maps during S-type SDS-episodes (indicated on Figure S4) at arrival heights (a) 100 m, (b) 500 m, and (c) $1500 \mathrm{~m}$. The arrival location was the campus of the University of Jordan, Amman, Jordan. These maps were generated from the hourly back trajectories during the sampling dates (+ following day), Figure S6: Back trajectories $(96 \mathrm{~h}$ ) crossing maps during SL-type SDS-episodes (indicated on Figure S4) at arrival heights (a) $100 \mathrm{~m}$, (b) $500 \mathrm{~m}$, and (c) $1500 \mathrm{~m}$. The arrival location was the campus of the University of Jordan, Amman, Jordan. These maps were generated from the hourly back trajectories during the sampling dates (+ following day), Figure S7: Back trajectories $(96 \mathrm{~h}$ ) crossing maps during SLA-type SDS-episodes (indicated on Figure S4) at arrival heights (a) 100 m, (b) 500 m, and (c) $1500 \mathrm{~m}$. The arrival location was the campus of the University of Jordan, Amman, Jordan. These maps were generated from the hourly back trajectories during the sampling dates (+ following day), Figure S8: Back trajectories $(96 \mathrm{~h}$ ) crossing maps during low PM10 concentrations (indicated on Figure S4) at arrival heights (a) $100 \mathrm{~m}$, (b) $500 \mathrm{~m}$, and (c) $1500 \mathrm{~m}$. The arrival location was the campus of the University of Jordan, Amman, Jordan. These maps were generated from the hourly back trajectories during the sampling dates (+ following day), Table S1: Particulate matter concentrations and overall average temperature and pressure according to the sampling schedule. The aerosol sampler reported the 24-h mean temperature $(\mathrm{T})$ and pressure $(\mathrm{P})$ during sampling sessions, Table S2: PM2.5 and PM10 concentrations $\left(\mu \mathrm{g} \mathrm{m}^{-3}\right)$ and corresponding OC and EC concentrations $\left(\mu \mathrm{g} \mathrm{m}^{-3}\right)$, Table S3: Sand and Dust Storm (SDS) episodes according to type and observation during the sampling period. The type of SDS is denoted as: Saharan (S); Saharan and Levant (SL); Saharan, Arabian, and Levant (SAL); Saharan, Arabian, Levant, and Ahvaz (SALA). The source region was verified according to the back trajectories analysis for crossing maps on the sampling day (+ following day). The date here indicates the start of the sampling day.

Author Contributions: Conceptualization, T.H. and M.V.; methodology, T.H., A.A.-H., S.A., A.A., and M.V.; validation, T.H., M.V., A.A., and Z.B.; formal analysis, T.H., Z.B., and X.L.; investigation, T.H., A.A.-H., T.P., S.A., and M.V.; resources, T.H., T.P., and M.V.; data curation, X.L., and Z.B.; writing—original draft preparation, T.H., M.V., A.A.-H., Z.B., and X.L.; writing—review and editing, T.H., X.L., Z.B., A.A., S.A., A.A.-H., M.V., and T.P.; visualization, X.L., Z.B., and T.H.; supervision, T.H., S.A., A.A.-H., and M.V.; project administration, T.H. and M.V.; funding acquisition, T.H. All authors have read and agreed to the published version of the manuscript.

Funding: This research was funded by the Deanship of Academic Research (DAR, project number 2015) at the University of Jordan. Academy of Finland Center of Excellence (project No. 272041). eCOST action (inDUST, project number CA16202) support via the Short Term Scientific Mission (STSM) mobility grant.

Institutional Review Board Statement: Not applicable.

Informed Consent Statement: Not applicable.

Data Availability Statement: Data will be available upon request.

Acknowledgments: This research was part of a close collaboration between the University of Jordan, the Institute of Environmental Assessment and Water Research (IDAEA-CSIC), and the Institute for Atmospheric and Earth System Research (INAR/Physics, University of Helsinki). We acknowledge the financial support provided by the Deanship of Academic Research (DAR, project No. 2015) at the University of Jordan, Academy of Finland Center of Excellence (project No. 272041), ERA- 
PLANET, trans-national project SMURBS (grant agreement n. 689443 funded under the EU Horizon 2020 Framework Programme and Academy of Finland via the Center of Excellence in Atmospheric sciences and NanoBioMass (project number 1307537). The eCOST action (inDUST, project number CA16202) is acknowledged for supporting this research via the Short Term Scientific Mission (STSM) mobility grant. The work was supported by the Spanish Ministry of Science and Innovation (Project CEX2018-000794-S) and by AGAUR (project 2017 SGR41). This manuscript was written and completed during the sabbatical leave of the first author (Tareq Hussein) that was spent at the University of Helsinki and supported by the University of Jordan during 2019.

Conflicts of Interest: The authors declare no conflict of interest.

\section{References}

1. Geron, C. Carbonaceous aerosol over a Pinus taeda forest in Central North Carolina, USA. Atmos. Environ. 2009, 43, 959-969. [CrossRef]

2. Lin, P.; Hu, M.; Deng, Z.; Slanina, J.; Han, S.; Kondo, Y.; Takegawa, N.; Miyazaki, Y.; Zhao, Y.; Sugimoto, N. Seasonal and diurnal variations of organic carbon in $\mathrm{PM}_{2.5}$ in Beijing and the estimation of secondary organic carbon. J. Geophys. Res. 2009, 114, D00G11. [CrossRef]

3. von Schneidemesser, E.; Zhou, J.; Stone, E.A.; Schauer, J.J.; Qasrawi, R.; Abdeen, Z.; Shpund, J.; Vanger, A.; Sharf, G.; Moise, T.; et al. Seasonal and spatial trends in the sources of fine particle organic carbon in Israel, Jordan, and Palestine. Atmos. Environ. 2010, 44, 3669-3678. [CrossRef]

4. Carrico, C.M.; Bergin, M.H.; Shrestha, A.B.; Dibb, J.E.; Gomes, L.; Harris, J.M. The importance of carbon and mineral dust to seasonal aerosol properties in the Nepal Himalaya. Atmos. Environ. 2003, 37, 2811-2824. [CrossRef]

5. Schauer, J.J.; Rogge, W.F.; Hildemann, L.M.; Mazurek, M.A.; Cass, G.R.; Simoneit, B.R.T. Source apportionment of airborne particulate matter using organic compounds as tracers. Atmos. Environ. 1996, 30, 3837-3855. [CrossRef]

6. Sillanpää, M.; Frey, A.; Hillamo, R.; Pennanen, A.S.; Salonen, R.O. Organic, elemental and inorganic carbon in particulate matter of six urban environments in Europe. Atmos. Chem. Phys. 2005, 5, 2869-2879. [CrossRef]

7. Stone, E.A.; Snyder, D.C.; Sheesley, R.J.; Sullivan, A.P.; Weber, R.J.; Schauer, J.J. Source apportionment of fine organic aerosol in Mexico City during the MILAGRO experiment 2006. Atmos. Chem. Phys. 2008, 8, 1249-1259. [CrossRef]

8. Kanakidou, M.; Seinfeld, J.H.; Pandis, S.N.; Barnes, I.; Dentener, F.J.; Facchini, M.C.; van Dingenen, R.; Ervens, B.; Nenes, A.; Nielsen, C.J.; et al. Organic aerosol and global climate modelling: A review. Atmos. Chem. Phys. 2005, 5, 1053-1123. [CrossRef]

9. Bond, T.C.; Doherty, S.J.; Fahey, D.W.; Forster, P.M.; Berntsen, T.; Deangelo, B.J.; Flanner, M.G.; Ghan, S.; Kärcher, B.; Koch, D.; et al. Bounding the role of black carbon in the climate system: A scientific assessment. J. Geophys. Res. Atmos. 2013, 118, 5380-5552. [CrossRef]

10. Ramanathan, V.; Carmichael, G. Global and regional climate changes due to black carbon. Nat. Geosci. 2008, 1, 221-227. [CrossRef]

11. Robinson, A.L.; Donahue, N.M.; Shrivastava, M.K.; Weitkamp, E.A.; Sage, A.M.; Grieshop, A.P.; Lane, T.E.; Pierce, J.R.; Pandis, S.N. Rethinking organic aerosols: Semivolatile emissions and photochemical aging. Science 2007, 315, 1259-1262. [CrossRef] [PubMed]

12. McMurry, P.; Shepherd, M.; Vickery, J. Particulate Matter Science for Policy Makers: A Narsto Assessment; Cambridge University Press: New York, NY, USA, 2004.

13. Hu, Y.; Odman, M.T.; Russell, A.G. Top-down analysis of the elemental carbon emissions inventory in the United States by inverse modeling using Community Multiscale Air Quality model with decoupled direct method (CMAQ-DDM). J. Geophys. Res. Atmos. 2009, 114, 11987. [CrossRef]

14. Zhu, J.J.; Chen, Y.C.; Shie, R.H.; Liu, Z.S.; Hsu, C.Y. Predicting carbonaceous aerosols and identifying their source contribution with advanced approaches. Chemosphere 2021, 266, 128966. [CrossRef] [PubMed]

15. Jacobson, M.Z. Strong radiative heating due to the mixing state of black carbon in atmospheric aerosols. Nature 2001, 409, 695-697. [CrossRef] [PubMed]

16. Menon, S.; Hansen, J.; Nazarenko, L.; Luo, Y. Climate effects of black carbon aerosols in China and India. Science 2002, 297, 2250-2253. [CrossRef]

17. Turpin, B.J.; Huntzicker, J.J. Identification of secondary organic aerosol episodes and quantitation of primary and secondary organic aerosol concentrations during SCAQS. Atmos. Environ. 1995, 29, 3527-3544. [CrossRef]

18. Feng, Y.; Ramanathan, V.; Kotamarthi, V.R. Brown carbon: A significant atmospheric absorber of solar radiation? Atmos. Chem. Phys. 2013, 13, 8607-8621. [CrossRef]

19. Laskin, A.; Laskin, J.; Nizkorodov, S.A. Chemistry of Atmospheric Brown Carbon. Chem. Rev. 2015, 115, 4335-4382. [CrossRef]

20. Pandey, A.; Hsu, A.; Tiwari, S.; Pervez, S.; Chakrabarty, R.K. Light absorption by organic aerosol emissions rivals that of black carbon from residential biomass fuels in South Asia. Environ. Sci. Technol. Lett. 2020, 7, 266-272. [CrossRef]

21. Pani, S.K.; Lin, N.-H.; Griffith, S.M.; Chantara, S.; Lee, C.-T.; Thepnuan, D.; Tsai, Y.I. Brown carbon light absorption over an urban environment in northern peninsular Southeast Asia. Environ. Pollut. 2021, 276, 116735. [CrossRef]

22. Chuang, K.J.; Chan, C.C.; Su, T.C.; Lee, C.T.; Tang, C.S. The effect of urban air pollution on inflammation, oxidative stress, coagulation, and autonomic dysfunction in young adults. Am. J. Respir. Crit. Care Med. 2007, 176, 370-376. [CrossRef] [PubMed] 
23. Ostro, B.; Feng, W.Y.; Broadwin, R.; Green, S.; Lipsett, M. The effects of components of fine particulate air pollution on mortality in California: Results from CALFINE. Environ. Health Perspect. 2007, 115, 13-19. [CrossRef] [PubMed]

24. Peng, R.D.; Bell, M.L.; Geyh, A.S.; McDermott, A.; Zeger, S.L.; Samet, J.M.; Dominici, F. Emergency admissions for cardiovascular and respiratory diseases and the chemical composition of fine particle air pollution. Environ. Health Perspect. 2009, 117, 957-963. [CrossRef] [PubMed]

25. Zhou, J.; Ito, K.; Lall, R.; Lippmann, M.; Thurston, G. Time-series analysis of mortality effects of fine particulate matter components in Detroit and seattle. Environ. Health Perspect. 2011, 119, 461-466. [CrossRef]

26. Wang, Y.C.; Lin, Y.K. Mortality associated with particulate concentration and Asian dust storms in Metropolitan Taipei. Atmos. Environ. 2015, 117, 32-40. [CrossRef]

27. Pope, C.A.; Dockery, D.W. Health Effects of Fine Particulate Air Pollution: Lines that Connect. J. Air Waste Manag. Assoc. 2006, 56, 709-742. [CrossRef]

28. Pope III, C.A. Lung Cancer, Cardiopulmonary Mortality, and Long-term Exposure to Fine Particulate Air Pollution. JAMA 2002, 287, 1132-1141. [CrossRef]

29. Hoek, G.; Krishnan, R.M.; Beelen, R.; Peters, A.; Ostro, B.; Brunekreef, B.; Kaufman, J.D. Long-term air pollution exposure and cardio- respiratory mortality: A review. J. Environ. Health 2013, 12, 43. [CrossRef]

30. Engling, G.; Gelencsér, A. Atmospheric brown clouds: From local air pollution to climate change. Elements 2010, 6, 223-228. [CrossRef]

31. Park, R.J.; Jacob, D.J.; Chin, M.; Martin, R.V. Sources of carbonaceous aerosols over the United States and implications for natural visibility. J. Geophys. Res. Atmos. 2003, 108, 12. [CrossRef]

32. Mauderly, J.L.; Chow, J.C. Health effects of organic aerosols. Inhal. Toxicol. 2008, 20, 257-288. [CrossRef] [PubMed]

33. Small, I.; van der Meer, J.; Upshur, R.E. Acting on an environmental health disaster: The case of the Aral Sea. Environ. Health Perspect. 2001, 109, 547-549. [CrossRef] [PubMed]

34. Menéndez, I.; Díaz-Hernández, J.L.; Mangas, J.; Alonso, I.; Sánchez-Soto, P.J. Airborne dust accumulation and soil development in the North-East sector of Gran Canaria (Canary Islands, Spain). J. Arid Environ. 2007, 71, 57-81. [CrossRef]

35. McTainsh, G.; Strong, C. The role of aeolian dust in ecosystems. Geomorphology 2007, 89, 39-54. [CrossRef]

36. Goudie, A.S. Dust storms: Recent developments. J. Environ. Manag. 2009, 90, 89-94. [CrossRef]

37. Karanasiou, A.; Moreno, N.; Moreno, T.; Viana, M.; de Leeuw, F.; Querol, X. Health effects from Sahara dust episodes in Europe: Literature review and research gaps. Environ. Int. 2012, 47, 107-114. [CrossRef]

38. Rezazadeh, M.; Irannejad, P.; Shao, Y. Climatology of the Middle East dust events. Aeolian Res. 2013, 10, 103-109. [CrossRef]

39. Almasi, A.; Mousavi, A.R.; Bakhshi, S.; Namdari, F. Dust storms and environmental health impacts. J. Middle East Appl. Sci. Technol. 2014, 8, 353-356.

40. Goudie, A.S. Desert dust and human health disorders. Environ. Int. 2014, 63, 101-113. [CrossRef]

41. Díaz, J.; Linares, C.; Carmona, R.; Russo, A.; Ortiz, C.; Salvador, P.; Trigo, R.M. Saharan dust intrusions in Spain: Health impacts and associated synoptic conditions. Environ. Res. 2017, 156, 455-467. [CrossRef]

42. Middleton, N.J. Desert dust hazards: A global review. Aeolian Res. 2017, 24, 53-63. [CrossRef]

43. Contini, D.; Vecchi, R.; Viana, M. Carbonaceous aerosols in the atmosphere. Atmosphere 2018, 9, 181. [CrossRef]

44. Hussein, T.; Li, X.; Al-Dulaimi, Q.; Daour, S.; Atashi, N.; Viana, M.; Alastuey, A.; Sogacheva, L.; Arar, S.; Al-Hunaiti, A.; et al. Particulate matter concentrations in a middle eastern city - an insight to sand and dust storm episodes. Aerosol Air Qual. Res. 2020, 20, 2780-2792. [CrossRef]

45. Querol, X.; Alastuey, A.; Rodrıguez, S.; Viana, M.M.; Artıñano, B.; Salvador, P.; Mantilla, E.; do Santos, S.G.; Patier, R.F.; de La Rosa, J.; et al. Levels of particulate matter in rural, urban and industrial sites in Spain. Sci. Total Environ. 2004, 334, 359-376. [CrossRef] [PubMed]

46. Birch, M.E.; Cary, R.A. Elemental Carbon-Based Method for Monitoring Occupational Exposures to Particulate Diesel Exhaust. Aerosol Sci. Technol. 1996, 25, 221-241. [CrossRef]

47. Cavalli, F.; Viana, M.; Yttri, K.E.; Genberg, J.; Putaud, J.-P. Toward a standardised thermal-optical protocol for measuring atmospheric organic and elemental carbon: The EUSAAR protocol. Atmos. Meas. Technol. 2010, 3, 79-89. [CrossRef]

48. Viana, M.; Maenhaut, W.; Chi, X.; Querol, X.; Alastuey, A. Comparative chemical mass closure of fine and coarse aerosols at two sites in south and west Europe: Implications for EU air pollution policies. Atmos. Environ. 2007, 41, 315-326. [CrossRef]

49. Draxler, R. Personal Communication (Memo); Hess, G.D., Ed.; Air Resources Laboratory: Silver Spring, MD, USA; Bureau of Meteorology Research Centre: Melbourne, Australia, 1997.

50. Stein, A.F.; Draxler, R.R.; Rolph, G.D.; Stunder, B.J.B.; Cohen, M.D.; Ngan, F. NOAA's HYSPLIT Atmospheric Transport and Dispersion Modeling System. Bull. Am. Meteorol. Soc. 2015, 96, 2059-2077. [CrossRef]

51. Ambient (Outdoor) Air Quality Database 2018 by Country and City. Available online: https://www.who.int/airpollution/data/ aap_air_quality_database_2018_v14.xlsx?ua=1,ap_air_quality_database_2018_v14.xlsx (accessed on 20 March 2020).

52. WHO Global Air Quality Guidelines. Available online: https://apps.who.int/iris/bitstream/handle/10665/345329/978924003 4228-eng.pdf?sequence=1andisAllowed=y (accessed on 28 November 2021).

53. Millet, D.B. Atmospheric volatile organic compound measurements during the Pittsburgh Air Quality Study: Results, interpretation, and quantification of primary and secondary contributions. J. Geophys. Res. 2005, 110, D07S07. [CrossRef] 
54. Saarikoski, S.; Timonen, H.; Saarnio, K.; Aurela, M.; Järvi, L.; Keronen, P.; Kerminen, V.-M.; Hillamo, R. Sources of organic carbon in fine particulate matter in northern European urban air. Atmos. Chem. Phys. 2008, 8, 6281-6295. [CrossRef]

55. Genberg, J.; Hyder, M.; Stenström, K.; Bergström, R.; Simpson, D.; Fors, E.O.; Jönsson, J.Å.; Swietlicki, E. Source apportionment of carbonaceous aerosol in southern Sweden. Atmos. Chem. Phys. 2011, 11, 11387-11400. [CrossRef]

56. Hu, W.W.; Hu, M.; Deng, Z.Q.; Xiao, R.; Kondo, Y.; Takegawa, N.; Zhao, Y.J.; Guo, S.; Zhang, Y.H. The characteristics and origins of carbonaceous aerosol at a rural site of PRD in summer of 2006. Atmos. Chem. Phys. 2012, 12, 1811-1822. [CrossRef]

57. Vodička, P.; Schwarz, J.; Ždímal, V. Analysis of one year's OC/EC data at a Prague suburban site with 2-h time resolution. Atmos. Environ. 2013, 77, 865-872. [CrossRef]

58. Heal, M.R.; Hammonds, M.D. Insights into the Composition and Sources of Rural, Urban and Roadside Carbonaceous PM 10 . Environ. Sci. Technol. 2014, 48, 8995-9003. [CrossRef] [PubMed]

59. Huang, X.H.H.; Bian, Q.J.; Louie, P.K.K.; Yu, J.Z. Contributions of vehicular carbonaceous aerosols to $\mathrm{PM}_{2.5}$ in a roadside environment in Hong Kong. Atmos. Chem. Phys. 2014, 14, 9279-9293. [CrossRef]

60. Huang, X.H.; Bian, Q.; Ng, W.M.; Louie, P.K.; Yu, J.Z. Characterization of PM2.5 Major Components and Source Investigation in Suburban Hong Kong: A One Year Monitoring Study. Aerosol Air Qual. Res. 2014, 14, 237-250. [CrossRef]

61. He, K.; Yang, F.; Ma, Y.; Zhang, Q.; Yao, X.; Chan, C.K.; Cadle, S.; Chan, T.; Mulawa, P. The characteristics of PM 2.5 in Beijing, China. Atmos. Environ. 2001, 35, 4959-4970. [CrossRef]

62. Kim, Y.P.; Moon, K.C.; Lee, J.H.; Baik, N.J. Concentrations of carbonaceous species in particles at Seoul and Cheju in Korea. Atmos. Environ. 1999, 33, 2751-2758. [CrossRef]

63. Yamagami, M.; Ikemori, F.; Nakashima, H.; Hisatsune, K.; Ueda, K.; Wakamatsu, S.; Osada, K. Trends in PM ${ }_{2.5}$ Concentration in Nagoya, Japan, from 2003 to 2018 and Impacts of PM 2.5 Countermeasures. Atmosphere 2021, 12, 590. [CrossRef]

64. Maykut, N.N.; Lewtas, J.; Kim, E.; Larson, T.V. Source apportionment of $\mathrm{PM}_{2 .} 5$ at an urban IMPROVE site in Seattle, Washington. Environ. Sci. Technol. 2003, 37, 5135-5142. [CrossRef]

65. Bian, Q.; Alharbi, B.; Shareef, M.M.; Husain, T.; Pasha, M.J.; Atwood, S.A.; Kreidenweis, S.M. Sources of PM2.5 carbonaceous aerosol in Riyadh, Saudi Arabia. Atmos. Chem. Phys. 2018, 18, 3969-3985. [CrossRef]

66. Grivas, G.; Cheristanidis, S.; Chaloulakou, A. Elemental and organic carbon in the urban environment of Athens. Seasonal and diurnal variations and estimates of secondary organic carbon. Sci. Total Environ. 2012, 414, 535-545. [CrossRef] [PubMed]

67. Arfaeinia, H.; Hashemi, S.E.; Alamolhoda, A.A.; Kermani, M. Evaluation of organic carbon, elemental carbon, and water soluble organic carbon concentration in $\mathrm{PM}_{2.5}$ in the ambient air of Sina Hospital district, Tehran, Iran. J. Adv. Environ. Health Res. 2016, 4, 95-101. [CrossRef]

68. Brown, K.W.; Bouhamra, W.; Lamoureux, D.P.; Evans, J.S.; Koutrakis, P. Characterization of particulate matter for three sites in Kuwait. J. Air Waste Manag. Assoc. 2008, 58, 994-1003. [CrossRef] [PubMed]

69. Waked, A.; Afif, C.; Brioude, J.; Formenti, P.; Chevaillier, S.; Haddad, I.E.; Seigneur, C. Composition and source apportionment of organic aerosol in Beirut, Lebanon, during winter 2012. Aerosol Sci. Technol. 2013, 47, 1258-1266. [CrossRef]

70. Juda-Rezler, K.; Reizer, M.; Maciejewska, K.; Błaszczak, B.; Klejnowski, K. Characterization of atmospheric PM2.5 sources at a Central European urban background site. Sci. Total Environ. 2020, 713, 136729. [CrossRef]

71. Viana, M.; Chi, X.; Maenhaut, W.; Querol, X.; Alastuey, A.; Mikuška, P.; Večeřa, Z. Organic and elemental carbon concentrations in carbonaceous aerosols during summer and winter sampling campaigns in Barcelona, Spain. Atmos. Environ. 2006, 40, 2180-2193. [CrossRef]

72. Siciliano, T.; Siciliano, M.; Malitesta, C.; Proto, A.; Cucciniello, R.; Giove, A.; Genga, A. Carbonaceous $\mathrm{PM}_{10}$ and PM 2.5 and secondary organic aerosol in a coastal rural site near Brindisi (Southern Italy). Environ. Sci. Pollut. Res. 2018, 25, 23929-23945. [CrossRef]

73. Khan, M.B.; Masiol, M.; Formenton, G.; Di Gilio, A.; de Gennaro, G.; Agostinelli, C.; Pavoni, B. Carbonaceous PM 2.5 and secondary organic aerosol across the Veneto region (NE Italy). Sci. Total Environ. 2016, 542, 172-181. [CrossRef]

74. Tian, Y.Z.; Xiao, Z.M.; Han, B.; Shi, G.L.; Wang, W.; Hao, H.Z.; Zhu, T. Seasonal study of primary and secondary sources of carbonaceous species in $\mathrm{PM}_{10}$ from five northern Chinese cities. Aerosol Air Qual. Res. 2013, 13, 148-161. [CrossRef]

75. Arif, M.; Kumar, R.; Kumar, R.; Zusman, E.; Singh, R.P.; Gupta, A. Assessment of indoor \& outdoor black carbon emissions in rural areas of Indo-Gangetic Plain: Seasonal characteristics, source apportionment and radiative forcing. Atmos. Environ. 2018, 191, 227-240. [CrossRef]

76. Salmon, L.G.; Mayo, P.R.; Cass, G.R.; Seinfeld, J.H. Determination of Elemental Carbon and Organic Carbon Concentrations During the Southern California Children's Health Study, 1999-2001; Final report preparaed for the California Air Resources Board and the California Environmental Protection Agency, Research Division, University of California: Berkeley, CA, USA, 2004.

77. Alam, K.; Mukhtar, A.; Shahid, I.; Blaschke, T.; Majid, H.; Rahman, S.; Rahman, N. Source apportionment and characterization of particulate matter $\left(\mathrm{PM}_{10}\right)$ in urban environment of Lahore. Aerosol Air Qual. Res. 2014, 14, 1851-1861. [CrossRef]

78. Samara, C.; Voutsa, D.; Kouras, A.; Eleftheriadis, K.; Maggos, T.; Saraga, D.; Petrakakis, M. Organic and elemental carbon associated to $\mathrm{PM}_{10}$ and $\mathrm{PM}_{2.5}$ at urban sites of northern Greece. Environ. Sci. Pollut. Res. 2014, 21, 1769-1785. [CrossRef] [PubMed]

79. Salma, I.; Chi, X.; Maenhaut, W. Elemental and organic carbon in urban canyon and background environments in Budapest, Hungary. Atmos. Environ. 2004, 38, 27-36. [CrossRef] 
80. Shrivastava, M.; Cappa, C.D.; Fan, J.; Goldstein, A.H.; Guenther, A.B.; Jimenez, J.L.; Kuang, C.; Laskin, A.; Martin, S.T.; Ng, N.L.; et al. Recent advances in understanding secondary organic aerosol: Implications for global climate forcing. Rev. Geophys. 2017, 55, 509-559. [CrossRef]

81. Manousakas, M.I.; Florou, K.; Pandis, S.N. Source Apportionment of Fine Organic and Inorganic Atmospheric Aerosol in an Urban Background Area in Greece. Atmosphere 2020, 11, 330. [CrossRef]

82. Chen, G.; Sosedova, Y.; Canonaco, F.; Fröhlich, R.; Tobler, A.; Vlachou, A.; Daellenbach, K.R.; Bozzetti, C.; Hueglin, C.; Graf, P.; et al. Time-dependent source apportionment of submicron organic aerosol for a rural site in an alpine valley using a rolling positive matrix factorisation (PMF) window. Atmos. Chem. Phys. 2021, 21, 15081-15101. [CrossRef] 